\title{
A Meta-Synthesis of Bibliometric Reviews of Research on Managing for Sustainability, 1982-2019
}

\author{
Philip Hallinger 1,2
}

check for updates

Citation: Hallinger, P. A Meta-Synthesis of Bibliometric Reviews of Research on Managing for Sustainability, 1982-2019. Sustainability 2021, 13, 3469. https://doi.org/10.3390/ su13063469

Academic Editor: Sanjay K. Pandey

Received: 13 February 2021

Accepted: 16 March 2021

Published: 21 March 2021

Publisher's Note: MDPI stays neutral with regard to jurisdictional claims in published maps and institutional affiliations.

Copyright: (C) 2021 by the author. Licensee MDPI, Basel, Switzerland. This article is an open access article distributed under the terms and conditions of the Creative Commons Attribution (CC BY) license (https:/ / creativecommons.org/licenses/by/ $4.0 /)$.
1 College of Management, Mahidol University, 69 Vipavadee Rangsit Rd., Bangkok 10400, Thailand; hallinger@gmail.com

2 Department of Educational Leadership and Management, University of Johannesburg, Auckland Park, Johannesburg, South Africa

\begin{abstract}
This review of research used meta-synthesis to integrate findings from seven bibliometric reviews of research on managing for sustainability in different management disciplines: leadership, human resource management, entrepreneurship management, innovation management, supply chain management, knowledge management, and strategic management. The purposes of the review were to document empirically key features of this knowledge base as well as to identify leading journals, and documents. The meta-synthesis analyzed bibliographic data associated with 9927 relevant documents sourced from the Scopus index. The review confirmed the existence of a large body of management research on sustainability. This research, which first emerged during the 1980s, has grown exponentially since 2010. Although authorship of this corpus has been concentrated in AngloAmerican-European (AAE) societies (60\%), the authors of this corpus represent 140 different societies. Moreover, there is a recent trend of increasing contributions from developing societies such as China, India, Malaysia, Brazil, and South Africa. There are large differences in the "between-discipline" proportion of research produced on sustainability topics, with knowledge management and supply chain management evidencing the largest and human resource management the smallest proportions of this literature. The review also provided insight into the most influential journals (e.g., Journal of Cleaner Production, Sustainability, International Journal of Production Economics, Business Strategy and the Environment) and documents in the literature on managing for sustainability. Document co-citation analysis yielded three key conceptual themes within this literature: Sustainable Supply Chain Management, Strategic Management of Resources for Sustainability, Social Entrepreneurship. This analysis further highlighted the central role that strategic management theories have played in shaping sustainability discourse across the different management disciplines.
\end{abstract}

Keywords: sustainability; sustainable development; management; bibliometric; review

\section{Introduction}

The birth of the modern "sustainable development" movement can be traced to issuance of the Brundtland Report [1] in 1987. Subsequently, a series of United Nations initiatives have both broadened and deepened interest in sustainability issues across a variety of policy domains and academic disciplines [2-4]. In 2015, the United Nations set 17 sustainable development goals that have reframed the international sustainability agenda around a broad but explicit set of social, environmental, and economic development objectives. Both organizations and societies have been encouraged to develop their own contextually suitable approaches for bringing these goals to life. This has led to a proliferation of approaches aimed at "managing for sustainability" [5-7].

The research literature on managing for sustainability has grown dramatically in the 30 years since issuance of the Brundtland Report [1]. This growth in sustainability research has been documented in research reviews conducted on management topics such as corporate social responsibility [8], corporate performance [9-11], product innovation [12], supply chain management [13], microcredit [14], and corporate governance [15]. 
Recently, these efforts were complemented by publication of a coordinated set of bibliometric reviews on managing for sustainability in seven functional management disciplines: entrepreneurship [16], organizational leadership [17], strategic management [18], supply chain management [19], human resource management [20], knowledge management [21], and innovation [22].

While these reviews documented trends in sustainability research within different management disciplines, there have been few systematic efforts to synthesize the evolving knowledge base on managing for sustainability across multiple disciplines. This represents the gap in the sustainability literature addressed in the current review of research. More specifically, this review of research applied bibliometric meta-synthesis in order to quantitatively integrate data from reviews of research on "managing for sustainability" in seven management disciplines. The research questions guiding this meta-synthesis were as follows.

1. What are the volume, disciplinary distribution, growth trajectory, and geographic distribution of published research on managing for sustainability?

2. What journals have been most influential in disseminating research on sustainability in seven key management disciplines?

3. What documents have had the greatest impact on research in managing for sustainability, and what key themes describe this literature?

In this review, the author synthesized data drawn from seven bibliometric reviews on sustainability in human resource management, organizational leadership, supply chain management, innovation, strategic management, knowledge management, and entrepreneurship [16-22]. The database analyzed in this review consisted of 9927 Scopusindexed documents identified in the prior reviews. Bibliometric analyses applied to this meta-database included descriptive analysis of document publication trends, as well as journal and document citation and co-citation analysis [23-25]. Since the meta-synthesis covers a significant range of the "core management disciplines", the review provides a broader perspective on the emerging knowledge base on managing for sustainability than previous efforts.

\section{Materials and Methods}

In contrast with narrative, scoping, and meta-analytic reviews of research, bibliometric reviews neither evaluate nor analyze findings reported in a set of studies. Instead, they analyze bibliographic meta-data associated with a large corpus of documents. The goals of a bibliometric review are to document and analyze characteristics of the knowledge base associated with a discipline or line of empirical inquiry [25]. Since this review analyzed secondary data extracted from previously published bibliometric reviews, it is classified as a "bibliometric meta-synthesis".

\subsection{Identification and Integration of the Review Documents}

The reliability of any "meta-review" depends on the comparability of the secondary data extracted from previously published studies. The viability of the current metasynthesis was enhanced by the fact that the seven contributing reviews extracted data from a common source, employed a consistent approach to document identification, and addressed similar research questions [16-22]. These commonalities facilitated data integration into a single database for this meta-synthesis and avoided some of the problems typically encountered in meta-reviews (e.g., incompatible data formats, diversity of metrics, incomplete data). A summary of the characteristics of the seven reviews is displayed in Table 1. 
Table 1. Descriptive characteristics of the composite bibliometric reviews of research on sustainability in seven management disciplines.

\begin{tabular}{|c|c|c|c|c|}
\hline Source & $\begin{array}{l}\text { Management } \\
\text { Discipline }\end{array}$ & $\begin{array}{l}\text { Number of } \\
\text { Documents }\end{array}$ & Time Frame & Document Types \\
\hline Thananusak, 2019 & $\begin{array}{l}\text { Entrepreneurship } \\
\text { Management }\end{array}$ & 712 & 1996-2019 & Mixed $^{2}$ \\
\hline Kainzbauer and Rungruang, 2019 & $\begin{array}{l}\text { Human Resource } \\
\text { Management }\end{array}$ & 475 & 1982-2019 & Mixed \\
\hline Hallinger and Suriyankietkaew, 2018 & $\begin{array}{l}\text { Organizational } \\
\text { Leadership }\end{array}$ & $1027^{3}$ & 1990-2019 & Mixed \\
\hline Vatananan-Thesenvitz, 2019 & $\begin{array}{l}\text { Innovation } \\
\text { Management }\end{array}$ & 1690 & 1985-2019 & Articles \\
\hline $\begin{array}{l}\text { Sanguankaew and Vathanophas } \\
\text { Ractham, } 2019\end{array}$ & $\begin{array}{l}\text { Knowledge } \\
\text { Management }\end{array}$ & $3234^{3}$ & 1994-2019 & Mixed \\
\hline Nimsai et al., 2020 & $\begin{array}{l}\text { Supply Chain } \\
\text { Management }\end{array}$ & $1801^{3}$ & 1995-2019 & Articles \\
\hline Suriyankietkaew and Petison, 2020 & Strategic Management & 988 & 1991-2019 & Mixed \\
\hline
\end{tabular}

The seven referenced bibliometric reviews all sourced documents from the Scopus index. Scopus is widely used to generate databases for bibliometric reviews in the social sciences due to its capabilities for exporting bibliographic meta-data and its broad coverage of relevant journals [25]. Indeed, empirical comparisons with the Web of Science have shown that Scopus offers more comprehensive coverage of relevant documents for research reviews in management and the social sciences [26]. As noted above, the common use of Scopus-indexed documents in the primary reviews ensured that the meta-synthesis would not be comparing "apples" (e.g., Scopus sourced documents) with "oranges" (e.g., Web of Science or Google Scholar sourced documents). From a technical perspective, the use of a common data source as well as the same data extraction procedures in the primary reviews also made it possible to combine the seven datasets into a single "composite dataset" for meta-synthesis.

In all seven of the sourced reviews, the authors had left the timeframe of their Scopus search undefined. This allowed the Scopus search engine to identify all relevant documents regardless of the date of publication. Therefore, Table 1 identifies the publication year of the "first relevant Scopus-indexed document" sourced in each of the reviews.

All of the reviews except Entrepreneurship, Innovation, and Supply Chain Management sourced a mixed set of Scopus-indexed documents consisting of journal articles, conference papers, books, and book chapters. This difference in the composition of the databases for the different management disciplines should be kept in mind when interpreting their relative sizes. For example, note that the sustainable supply chain database is comprised solely of journal articles. If conference papers, book chapters, and books had been included this database, it would have likely increased in size by about 15 to $20 \%$. Furthermore, since the reviews were not conducted by the same scholars, we note that the particular decision rules used to include/exclude documents could have led to a somewhat more generous or conservative interpretation of document eligibility.

All seven reviews followed PRISMA (Preferred Reporting Items for Systematic Reviews and Meta-Analyses) guidelines for conducting and reporting systematic reviews of research [27]. Thus, the reviews all contained detailed descriptions of the search terms, inclusion/exclusion criteria, and screening methods used to generate the databases. In each review, search terms associated with sustainability (e.g., sustainability, sustainable, green) were combined with relevant keywords specific to the particular discipline (e.g., organizational leadership, knowledge management, supply chain, logistics, etc.). 
Since "sustainability" is an trans-disciplinary field of research and practice, the initial Scopus searches often resulted in large databases that required filtering of duplicates and screening for topical relevance. For example, in his review of "sustainable entrepreneurship", Thananusak [16] generated an initial database of 1339 documents. However, after filtering ineligible document types, excluding duplicates, and screening for topical relevance, the final database was reduced to 712 documents. The specific procedures used to identify and screen documents for each review can be accessed in the original review articles [16-22].

The author contacted the authors for permission and access to the datasets used in the primary bibliometric reviews. In each instance, the data were stored in Microsoft Excel files. The author saved these "independent" Excel files in the csv format required by the VOSviewer software (version 1.6.8) used for data analysis [24]. In addition, a master Excel file was created that combined all of the data into a single worksheet for use in descriptive statistical analyses.

As noted in Table 1, however, three of the primary reviews had compiled databases through 2018. Therefore, the author updated the Scopus document search for these three reviews through the end of 2019 in order to maintain comparability among the databases. The additional document information was exported from Scopus and added to the master excel file used in data analysis. This master worksheet consisted of 9927 records (rows) of bibliographic meta-data (columns) exported from Scopus. These meta-data included author, document title, and related publication information, author affiliations, abstracts, funding details, citation data, and co-citation data.

\subsection{Data Synthesis}

The author used a dual analytical strategy for data synthesis. In some analyses, the author synthesized the findings reported in the primary reviews. However, for other analyses, the 9927 documents were reanalyzed as a single dataset. Data analyses were conducted in both Excel and VOSviewer software [23,24].

Prior to beginning data analysis, the bibliographic meta-data had to be cleaned through a process known as "disambiguation" [24]. Disambiguation refers to a process of checking and adjusting the bibliographic data for "consistency" in the expression of country, author, document, and journal names. For example, the journal Journal of Supply Chain Management was cited in the sourced documents using four alternate name formats: Journal of Supply Chain Management, J. Supply Chain Manag., J. Supply Chain Manag, and Jnl Supply Chain Manag. These different names for the same data item had to be identified and transformed into a common form prior to data analysis.

This was accomplished by creating a "thesaurus file", which provides instructions so that the analysis software replaces different forms of the same name with a common name. For example, this ensured that all records that referred to the J. Supply Chain Manag., J. Supply Chain Manag, and Jnl Supply Chain Manag. were replaced with the term Journal of Supply Chain Management during data analysis [24].) The thesaurus file created by the author was uploaded into VOSviewer software prior to initiating data analysis.

Descriptive trend analyses were conducted in order to document the size, growth trajectory, disciplinary breakdown, and geographical distribution of the knowledge base on managing for sustainability. Citation and co-citation analysis were used to identify influential journals and documents. Science mapping was used to visualize conceptual themes that comprise the literature in managing for sustainability [25].

"Citation analysis" conducted in VOSviewer 1.6.8 calculated the number of times a unit (i.e., document or journal) residing in the review database (i.e., 9927 documents) had been cited in other Scopus documents [28]. Citation analysis is perhaps the most commonly used method for determining scholarly impact [29]. However, citation analysis is limited to documents that reside in the source index (e.g., Scopus). Thus, citation counts obtained from document repositories differ depending upon their size [30,31]. As a result, citation counts based on Scopus tend to be larger than results obtained from the Web of 
Science but smaller than Google Scholar due to differences in the size of the respective document repositories.

Some limitations of citation analysis were mitigated in the current review through the complementary use of co-citation analysis [31]. As defined by Zupic and Čater [25], co-citation is "the frequency with which two units (journals, authors, documents) are cited together" (p. 431) in the reference lists of documents in the review database. For example, if document A authored by Seuring and Müller [32] and document B authored by Vachon and Klassen [33] appear in the reference list of a third document authored by Govindan and colleagues [34], then documents A and B each accrue one co-citation as well as a "link" (i.e., relational metric connecting documents A and B). Notably, because co-citation analysis is based on the "reference lists of the review documents", co-citation analysis is able to capture a broader literature.

Co-citation can also offer insight into "relationships" among documents or journals in a field of study. Proponents of co-citation analysis assert that frequent co-citation suggests a kind of intellectual affinity. For example, assume that the aforementioned documents authored by Seuring and Müller [32] and Vachon and Klassen [33] were frequently cited together in the reference lists of other documents contained in the review database. We could conclude that these frequently "co-cited documents" follow a similar theoretical tradition or are located within a similar line of inquiry [25].

Co-citation data are also used to map relationships among documents. In the current review, co-citation analysis in VOSviewer was used to create "science maps" of both document and journal contributions to the literature on managing for sustainability [25]. In these analyses, VOSviewer creates co-citation matrices that serve as the basis for the "visualization of similarities" (VOS) through bibliometric mapping [23,24]. As described by van Eck and Waltman [23], VOSViewer uses a technique "that aims to locate items in a low-dimensional space, in such a way that the distance between any two items reflects the similarity or relatedness of the items as accurately as possible" (p. 2407). Thus, both journal and document co-citation maps were generated in order to visualize relationships related to knowledge production. The goal of these analyses was to identify what Gmür [35] called the "invisible colleges" that comprise a field of study. These are "research networks that refer to each other in their documents without being linked by formal organizational ties" [27,35].

\section{Results}

\subsection{Trends in Knowledge Production on Sustainability in Management}

The first research question inquired into four features of the knowledge base on managing for sustainability: size, growth trajectory, disciplinary distribution, and geographical distribution. The review database consisted of 9927 Scopus-indexed documents published between 1982 and 2019. The database consisted of 71\% journal articles, 23\% conference papers, $4 \%$ book chapters, and $1 \%$ books. This represents a substantial inter-disciplinary knowledge base on managing for sustainability.

The reviews documented a common pattern of growth in the sustainability literatures across the seven management disciplines. This is reflected in the growth trajectory displayed in Figure 1, which is based on the composite set of 9927 documents. The growth trajectory of this literature evidenced slow growth during the late 1980s and 1990s, accelerating growth during the 2000s, and rapid growth since 2010. Overall, $78 \%$ of the Scopus-indexed literature on managing for sustainability has been published since 2010 . The most extreme example of this rapid growth trajectory was in supply chain management, where $89 \%$ of the Scopus-indexed documents had been published since 2010 and $68 \%$ had been published between 2016 and 2019. These data affirm a rapidly rising interest among management scholars in how sustainability challenges are being addressed in their disciplines. 


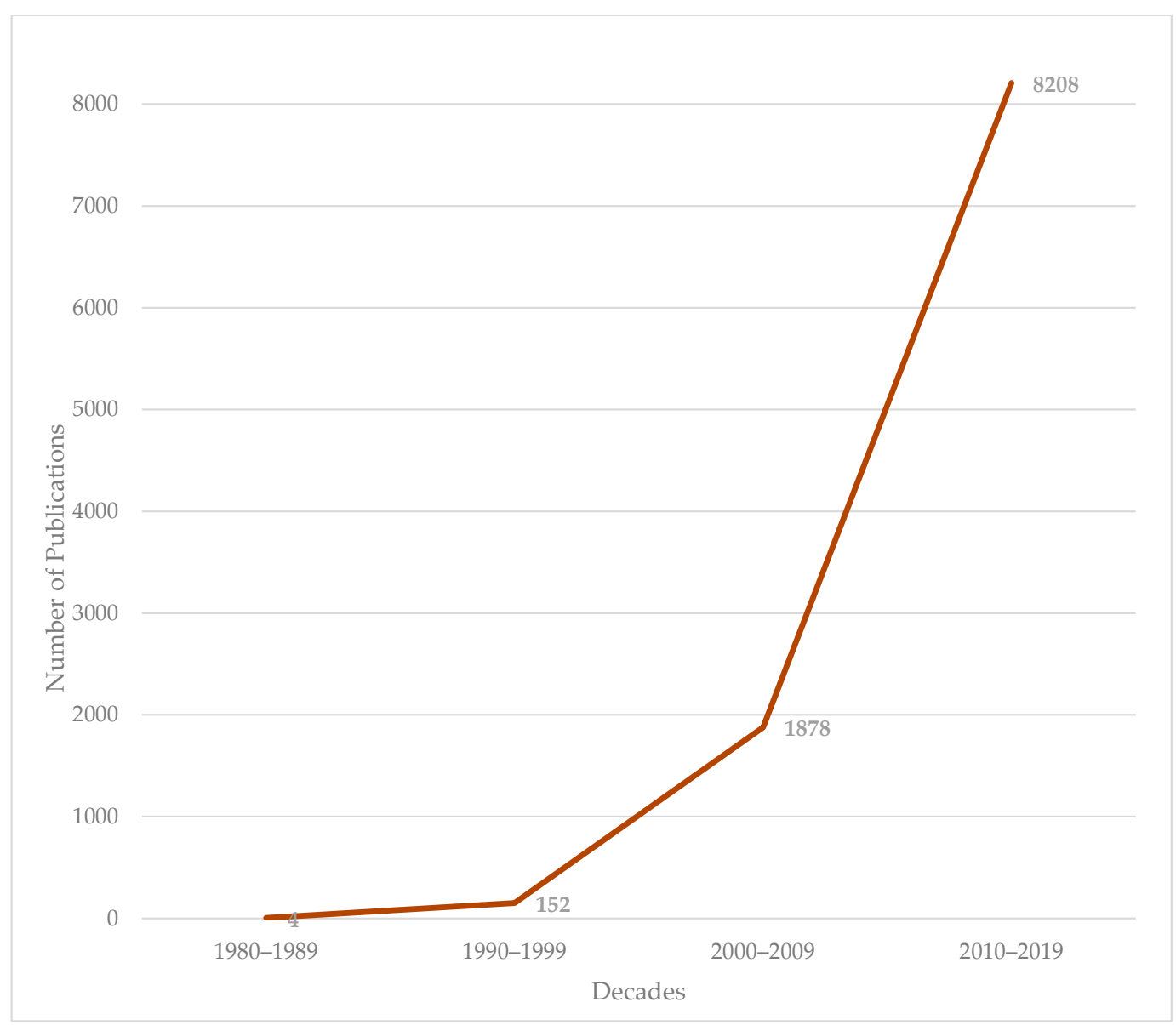

Figure 1. Growth trajectory of publications in seven management disciplines, 1982-2019 ( $n=9927$ documents).

However, at the same time, sustainability has attracted varying degrees of interest among scholars in the seven management disciplines (see Figure 2). The greatest interest in sustainability has come from scholars associated with knowledge management (KM), supply chain management (SCM), and innovation management. Surprisingly, sustainability issues have gained relatively little traction among scholars in human resource management. Note again that differences in how the reviews were conducted could have impacted, to some extent, the relative size of these literatures.

Analysis of the geographic distribution of research publications on managing for sustainability (see Figure 3) affirmed that interest among management scholars in sustainability is a truly worldwide literature. The research documents collected for this meta-synthesis were authored in 140 different societies. The geographical distribution of articles compiled in the seven management domains ranged from 65 to 107 societies.

Despite this global breadth of interest, the production of knowledge on managing for sustainability has been dominated by scholars located in Anglo-American-European (AAE) nations. These accounted for eight of the top 10 producers of sustainability research in management (see Figure 3). In most of these literatures, $60 \%$ or more of the documents were authored in AAE societies. Nonetheless, a recent trend has emerged with rising contributions from scholars in developing societies such as China, India, Malaysia, Brazil and South Africa. This was especially apparent in management domains such as supply chain management where Chinese scholars were among the global leaders in knowledge production. 


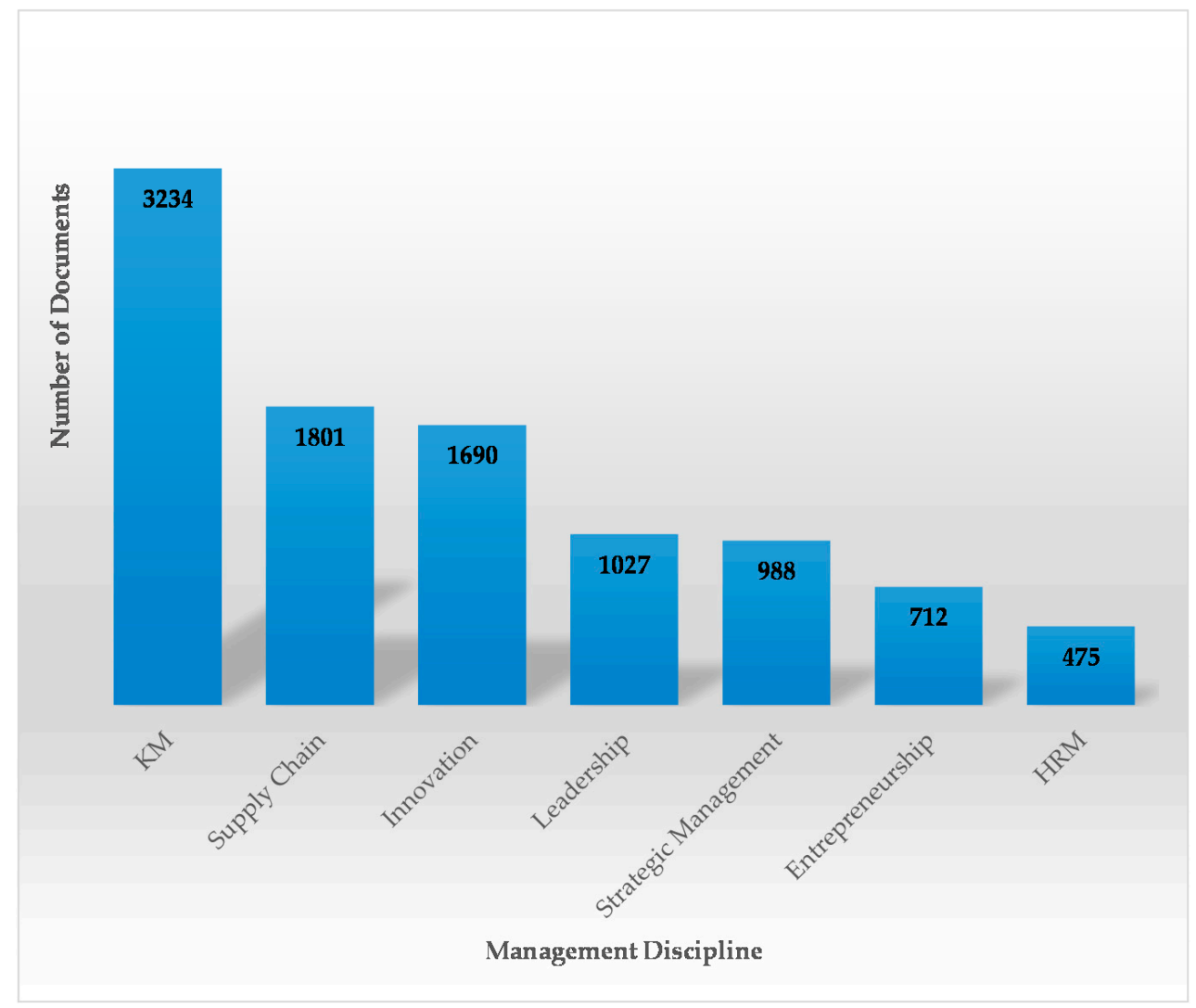

Figure 2. Size of the Scopus-indexed sustainability literatures in seven management disciplines ( $n=9927$ documents). $\mathrm{KM}=$ knowledge management; $\mathrm{HRM}=$ human resource management.

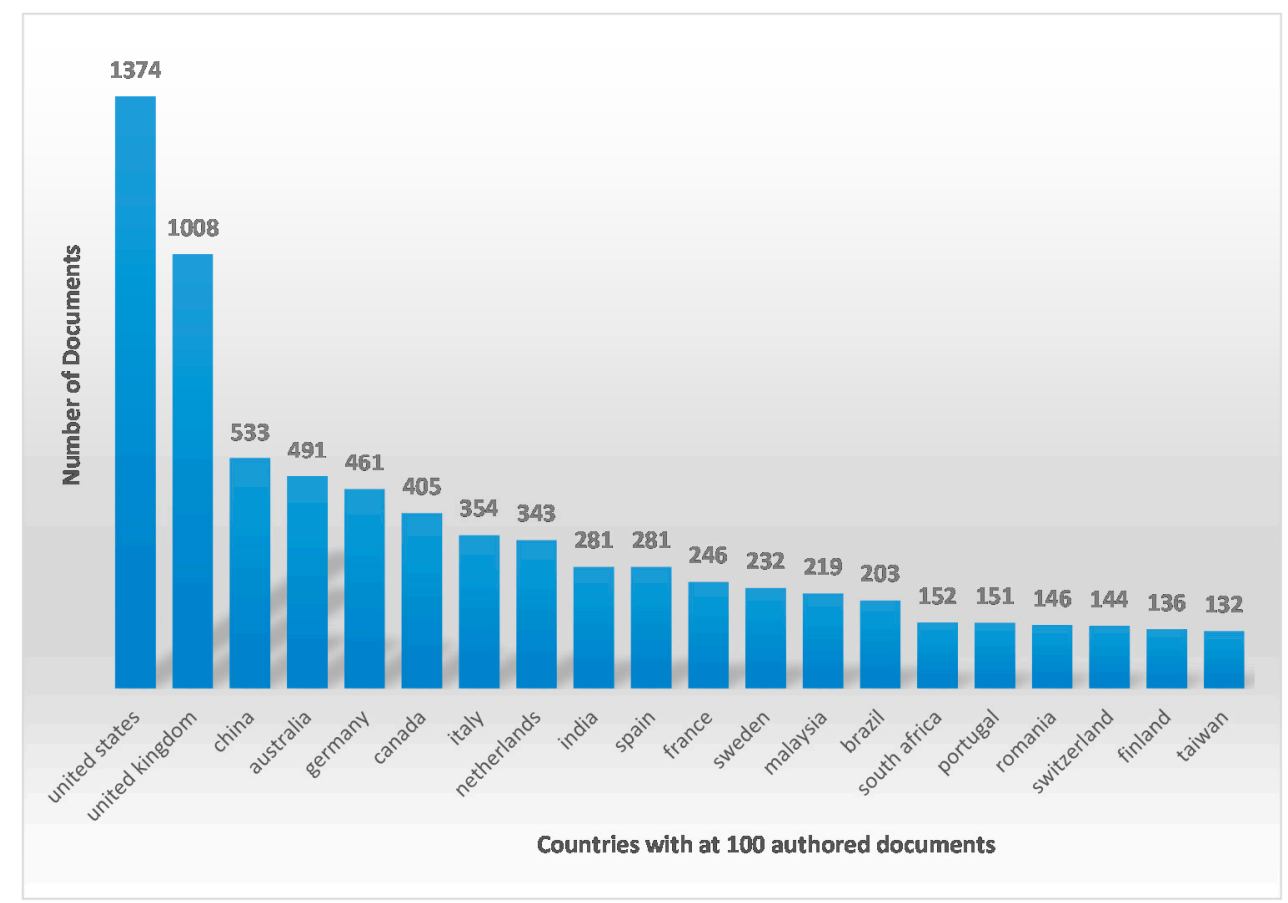

Figure 3. Countries producing the most publications on sustainability in the seven management disciplines. 


\subsection{Key Journals Publishing Research on Managing for Sustainability}

The next analyses focused on the role of journals in disseminating knowledge about managing for sustainability. As indicated in Table 2, relevant research has been published in journals associated with a rather wide range of scholarly disciplines. These include development (e.g., Sustainability, Sustainable Development, Journal of Sustainable Tourism), business management and strategy (e.g., Journal of Business Ethics, Business Strategy $\mathcal{E}$ Environment), operations management (International Journal of Production Economics, Supply Chain Management), information technology (e.g., Technological Forecasting and Social Change, Journal of Knowledge Management), and environmental sciences (e.g., Resources, Conservation and Recycling, Science of the Total Environment). While this diversity affirms cross-disciplinary interest in management processes aimed at achieving sustainable development goals, the list features a plurality [10] of journals associated with "operations and supply chain management". This highlights the extent to which sustainability has gained traction in this management discipline domain. Notably, Nimsai and Yoopetch [19] concluded in their review of research that the literature on sustainable supply chain management is heavily weighted toward the nexus of economic profitability and environmental impact, with far less attention to issues of social sustainability.

Table 2. Rank order of journals publishing the most articles on managing for sustainability.

\begin{tabular}{|c|c|c|c|c|c|c|c|}
\hline Rank & Journal & $\begin{array}{l}\text { Management } \\
\text { Discipline }\end{array}$ & Subject & Articles & $\begin{array}{l}\text { Scopus } \\
\text { Citations }\end{array}$ & $\mathrm{CPD}^{1}$ & $\begin{array}{l}\text { Scopus } \\
\text { Quartile }\end{array}$ \\
\hline 1 & $\begin{array}{l}\text { Journal of Cleaner } \\
\text { Production }\end{array}$ & Cross & Operations & 804 & 22,067 & 27 & Q1 96\% \\
\hline 2 & $\begin{array}{l}\text { Sustainability } \\
\text { (Switzerland) }\end{array}$ & Cross & Development & 569 & 2993 & 5 & Q1 90\% \\
\hline 3 & Intl Jnl of Production Econ & SCM & Operations & 150 & 8333 & 56 & Q1 98\% \\
\hline 4 & $\begin{array}{l}\text { Business Strategy } \mathcal{E} \\
\text { Environ }\end{array}$ & Strategy & Management & 95 & 3583 & 38 & Q1 99\% \\
\hline 5 & $\begin{array}{l}\text { Resources, Cons. E } \\
\text { Recycling }\end{array}$ & Environ & Environment & 93 & 2205 & 24 & Q1 98\% \\
\hline 6 & Intl Jnl of Prod Research & Operations & Operations & 84 & 3457 & 41 & Q1 90\% \\
\hline 7 & $\begin{array}{l}\text { Intl Jnl of Supply Chain } \\
\text { Man. }\end{array}$ & SCM & Operations & 84 & 208 & 2 & Q3 31\% \\
\hline 8 & $\begin{array}{l}\text { Supply Chain } \\
\text { Management }\end{array}$ & SCM & Operations & 74 & 4761 & 64 & Q1 94\% \\
\hline 9 & $\begin{array}{l}\text { Intl Jnl of Sust in Higher } \\
\text { Ed. }\end{array}$ & Education & Education & 56 & 1088 & 19 & Q1 86\% \\
\hline 10 & Journal of Business Ethics & Business & Management & 49 & 1197 & 24 & Q1 98\% \\
\hline 11 & Sustainable Development & Cross & Development & 48 & 1106 & 23 & Q1 96\% \\
\hline 12 & Eur. Jnl of Op. Research & Operations & Operations & 37 & 2297 & 62 & Q1 97\% \\
\hline 13 & Prod Planning and Control & Operations & Operations & 35 & 836 & 24 & Q1 90\% \\
\hline 14 & $\begin{array}{l}\text { Tech. Fore E Social } \\
\text { Change }\end{array}$ & Innovation & Information & 40 & 742 & 19 & Q1 92\% \\
\hline 15 & Intl Jnl of Op E Prod Man. & Operations & Operations & 33 & 2863 & 87 & Q1 95\% \\
\hline 16 & IFIP Adv in Comm \& Tech & Information & Information & 33 & 39 & 1 & Q3 30\% \\
\hline 17 & Comm. in Com E Info Sci & Information & Information & 32 & 31 & 1 & Q3 33\% \\
\hline 18 & Jnl of Sustainable Tourism & Geography & Development & 31 & 950 & 31 & Q1 95\% \\
\hline 19 & Strategic Direction & Strategy & Management & 30 & 9 & 0 & Q1 5\% \\
\hline 20 & Sustainability Science & Cross & Environment & 29 & 453 & 16 & Q1 $98 \%$ \\
\hline
\end{tabular}

${ }^{1}$ Citations per Document; NA = information not available; Cross = cross-disciplinary; SCM = supply chain management.

The journals that have published the most articles in this management domain are the Journal of Cleaner Production (781 articles), Sustainability (518), International Journal of Production Economics (137), Business Strategy and the Environment (96), Resources, Conservation and Recycling (88), International Journal of Production Research (79), and Supply Chain Management (72). Although journal citation impact does not mirror this order, these also represent the most influential journals in this field (see Table 2). It was 
interesting to note that although "knowledge management" ranked first in size among the seven management disciplines, no knowledge management journal has published a critical mass of articles on sustainability. This could be due to the inter-disciplinary nature of knowledge management [21].

Of additional significance is the quality of journals in which this literature has been published. A perusal of the Scopus rankings and percentiles clearly indicates that a critical mass of the literature on managing for sustainability is being published in some of the best journals across a range of disciplines. Moreover, the 20 journals listed in Table 2 accounted for $24 \%$ of the full literature sourced for this review (see Table 2). Therefore, although this review did not directly evaluate the quality of documents comprising this literature, the data I Table 2 suggest a very positive quality trend. More broadly, this analysis confirms that a wide range of high-quality journals are publishing content on managing for sustainability across different management disciplines.

Journal co-citation analysis was used to extend these insights into the nature and scope of contributions made by different journals to this literature. On the co-citation map in Figure 4, the size of a journal's "node" represents the relative frequency with which articles published in the journal were cited in the reference lists of documents in the review database. Proximity of nodes reflects the degree to which journals were co-cited together in these reference lists. Thus, for example, the map suggests that articles published in the Journal of Business Ethics and the Strategic Management Journal often appeared in the same reference lists. Proximity, therefore, suggests a similarity in the intellectual focus of the journals. Co-citation analysis also yields journal "clusters", indicated by colors. The journal clusters offer insight into the conceptual themes that comprise the literature $[23,36]$.

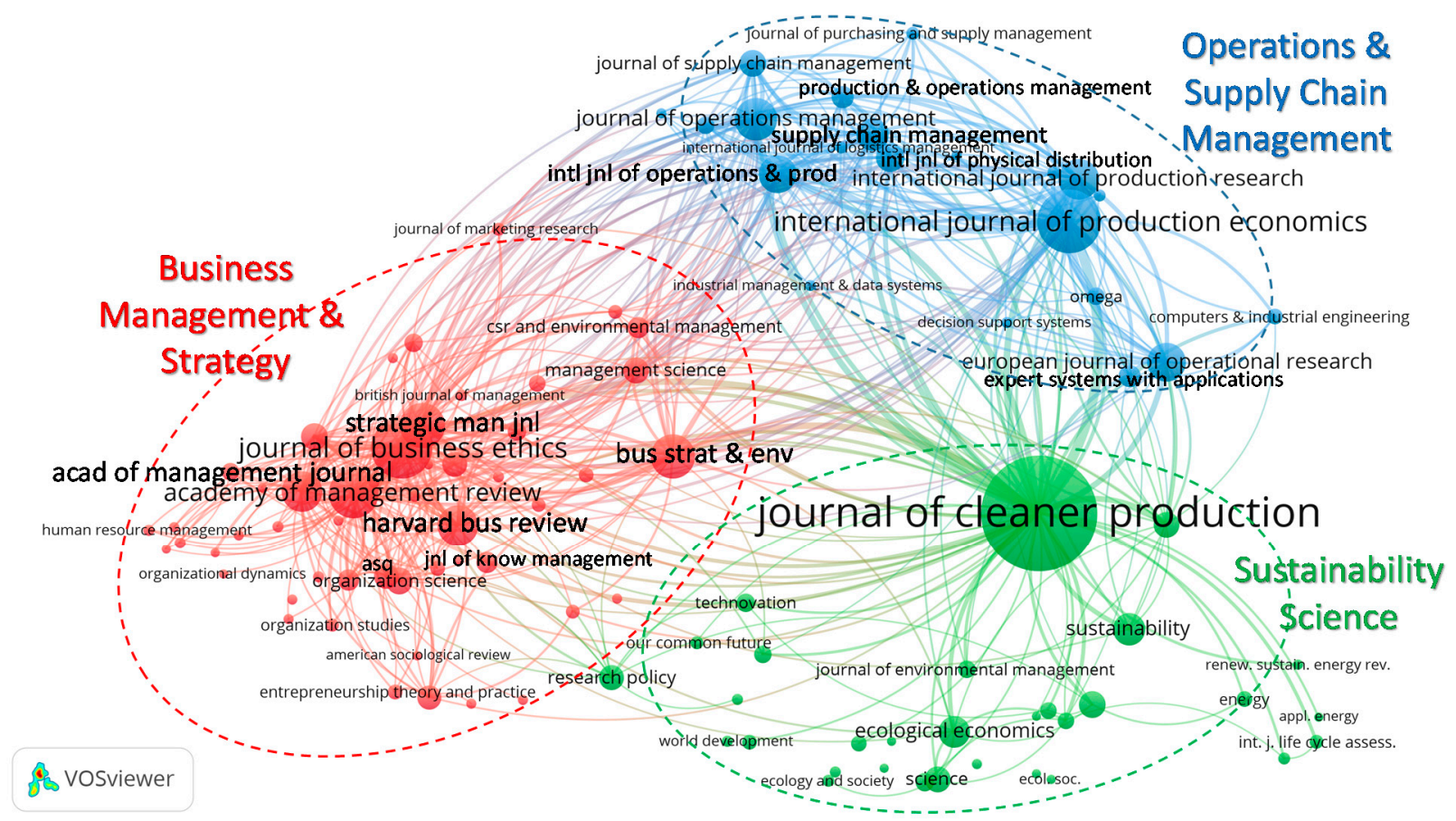

Figure 4. Journal co-citation analysis of the literature on managing for sustainability (threshold 250 citations, display 106 sources).

The top "co-cited journals" were the Journal of Cleaner Production (11,002 citations), International Journal of Production Economics (4464), Journal of Business Ethics (4201), Academy of Management Review (3136), Strategic Management Journal (2703), Business Strategy and the Environment (2600), Journal of Operations Management (2438), and the Harvard Business Review (2320). While there is overlap among the top-cited and top 
co-cited journals, the results are by no means identical. The added value of co-citation analysis is further illustrated by reference to the co-citation map in Figure 4.

This co-citation map highlights three journal clusters. The Sustainability Science cluster is anchored by the Journal of Cleaner Production. Journals located in this cluster tend to publish articles on sustainability topics but are not limited to management topics. Notably, this is the smallest and most dispersed of the three smallest clusters.

The largest cluster is comprised of journals that focus on Business Management and Strategy. This cluster is anchored by well-known management journals such as the Journal of Business Ethics, Academy of Management Review, Academy of Management Journal, Harvard Business Review, Strategic Management Journal, and Business Strategy \& the Environment. As indicated by reference to Table 2, some of these are located in this cluster due to the frequent publication of articles on sustainability (e.g., Journal of Business Ethics, Business Strategy $\mathcal{E}$ the Environment). However, as indicated by their omission from Table 2, some of these journals less frequently published articles on sustainability topics. Instead, their influence on this literature derives from frequent co-citation of articles they published on core management concepts. For example, Barney's [37] article on a resource-based view of competitive advantage published in the Journal of Management has been frequently co-cited in the managing for sustainability literature despite the fact that the article never mentions sustainability.

Despite evidencing fewer citations than some other journals in this cluster, Business Strategy \& the Environment deserves special mention. Note both its central position on the map and its numerous links to journals in all three clusters. This broad influence on the literature describes the position of a "boundary-spanning journal" whose content integrates important concepts across related but conceptually distinct domains.

The third cluster focuses on Operations and Supply Chain Management. This cluster includes a number of influential journals including International Journal of Production Economics, Supply Chain Management, and International Journal of Production Research. Journals located in this have published articles on sustainable supply chain management as well as sustainable production.

This analysis offers an expanded view of journal "influence" on discourse in managing for sustainability. Taking the multiple indicators of publication frequency, citation impact, and co-citation impact the Journal of Cleaner Production, International Journal of Production Economics, and Business Strategy and the Environment stand out as the premier journals publishing on sustainability in these management disciplines.

\subsection{Key Documents in Research on Managing for Sustainability}

The last syntheses conducted for this review aimed to identify key documents in the literature on managing for sustainability. The analytical strategy employed for this synthesis consisted of citation analysis, followed by document co-citation analysis and science mapping. Inspection of Table 3 finds that the top-cited documents on managing for sustainability have achieved very high levels of Scopus citation impact. This is especially notable because the earliest publication listed in Table 3 only appeared in 2004. In tandem with the rapidly accelerating growth trajectory of this literature shown earlier in Figure 1, the high level of "Scopus document citation impact" indicates that managing for sustainability has achieved high impact in a relatively short period of time. Moreover, a perusal of the scholars listed in Table 3 suggests that this emerging field has engaged the interest of mainstream management scholars as well as those specializing in sustainability issues. While some of these scholars are noted primarily for their research on "sustainability" within their management disciplines (e.g., Seuring, Müller, Austin, Mair, Vachon, Klassen, Sarkis, Zhu, Seyfang, Peredo), others are primarily known for their research outside of the domain of sustainability (e.g., Bansal, Helbing, Zahra, Geels, Pagell, Hatch, Dyer, Edvinsson, Hassini). 
Table 3. Most highly cited documents in the seven sustainability management disciplines.

\begin{tabular}{|c|c|c|c|c|c|}
\hline Rank & Documents & Subject & TBL Pillar(s) $^{1}$ & Type Paper ${ }^{2}$ & Scopus Cites \\
\hline 1 & $\begin{array}{l}\text { Seuring and Müller (2008). From a literature } \\
\text { review to a conceptual framework for } \\
\text { sustainable supply chain management [32]. }\end{array}$ & SCM & Env/Econ & Rev & 1926 \\
\hline 2 & $\begin{array}{l}\text { Austin et al. (2006). Social and commercial } \\
\text { entrepreneurship [38]. }\end{array}$ & Entre & Soc/Econ & Con & 1067 \\
\hline 3 & $\begin{array}{l}\text { Mair \& Marti (2006). Social entrepreneurship } \\
\text { research [39]. }\end{array}$ & Entre & Soc/Econ & Con & 1012 \\
\hline 4 & $\begin{array}{l}\text { Bansal (2005). Evolving sustainably [40]. } \\
\text { Chesbrough and Crowther. (2006). Beyond }\end{array}$ & Inno & Triple & Emp & 868 \\
\hline 5 & $\begin{array}{l}\text { high tech: Early adopters of open innovation } \\
\text { in other industries [ } 45] \text {. }\end{array}$ & Inno & Econ & Emp & 784 \\
\hline 6 & $\begin{array}{l}\text { Bettencourt et al. (2007). Growth, innovation, } \\
\text { scaling, and the pace of life in cities [46]. }\end{array}$ & $\mathrm{KM}$ & Soc/Econ & Con & 782 \\
\hline 7 & $\begin{array}{l}\text { Zahra et al. (2009). A typology of social } \\
\text { entrepreneurs [47]. }\end{array}$ & Entre & Soc & Con & 698 \\
\hline 8 & $\begin{array}{l}\text { Vachon and Klassen (2006). Extending green } \\
\text { practices across the supply chain [33]. }\end{array}$ & SCM & Env/Econ & Con & 666 \\
\hline 9 & $\begin{array}{l}\text { Zhu et al. (2005). Green supply chain } \\
\text { management in China: Pressures, practices } \\
\text { and performance [43]. }\end{array}$ & SCM & Env/Econ & Emp & 598 \\
\hline 10 & $\begin{array}{l}\text { Schot and Geels (2008). Strategic niche } \\
\text { management and sustainable innovation } \\
\text { journeys [42]. }\end{array}$ & Inno & Soc/Econ & $\operatorname{Rev}$ & 585 \\
\hline 11 & $\begin{array}{l}\text { Pagell and Wu Z. (2009). Building a more } \\
\text { complete theory of sustainable supply chain } \\
\text { management using case studies [48]. }\end{array}$ & SCM & Env/Econ & Emp & 583 \\
\hline 12 & $\begin{array}{l}\text { Hatch and Dyer (2004). Human capital and } \\
\text { learning as a source of sustainable competitive } \\
\text { advantage [49]. }\end{array}$ & $\mathrm{KM}$ & Soc/Econ & Con & 555 \\
\hline 13 & $\begin{array}{l}\text { Seyfang and Smith (2007). Grassroots } \\
\text { innovations for sustainable development [6]. }\end{array}$ & Inno & Triple & $\operatorname{Rev}$ & 553 \\
\hline 14 & $\begin{array}{l}\text { Edvinsson (1997). Developing intellectual } \\
\text { capital at Skandia [41]. }\end{array}$ & $\mathrm{KM}$ & Soc & Emp & 547 \\
\hline 15 & $\begin{array}{l}\text { Walker et al. (2008). Drivers and barriers to } \\
\text { environmental supply chain management } \\
\text { practices [50]. }\end{array}$ & SCM & Env/Econ & Con & 547 \\
\hline 16 & $\begin{array}{l}\text { Phaal et al. (2004). Technology } \\
\text { roadmapping-a planning framework for } \\
\text { evolution and revolution [51]. }\end{array}$ & & & & \\
\hline 17 & $\begin{array}{l}\text { Peredo and McLean (2006). Social } \\
\text { entrepreneurship [52]. }\end{array}$ & Entre & Soc & Rev & 516 \\
\hline 18 & $\begin{array}{l}\text { Zhu et al. (2007). Green supply chain } \\
\text { management [44]. }\end{array}$ & SCM & Env/Econ & Con & 490 \\
\hline 19 & $\begin{array}{l}\text { Mcnie. (2007). Reconciling the supply of } \\
\text { scientific information with user demands [53]. }\end{array}$ & Inno & Env & Rev & 485 \\
\hline 20 & $\begin{array}{l}\text { Wong. (2005). Critical success factors for } \\
\text { implementing knowledge management in } \\
\text { small and medium enterprises [54]. }\end{array}$ & KM & Econ & Con & 436 \\
\hline
\end{tabular}

${ }^{1}$ Env = environment; Soc = Social; Econ = Economic; Triple $=$ Triple Bottom Line ${ }^{2}$ con = conceptual; emp $=$ empirical; rev $=$ review of research.

It is also interesting to note that all of the 20 top-cited documents come from just four of the seven management disciplines covered in this review: supply chain management (seven documents), innovation (five), knowledge management (five), and entrepreneurship (four). They include a balance of conceptual papers (e.g., [33,38,39]), empirical reports (e.g., $[40,41]$, and reviews of research (e.g., [6,32,42]). The presence of several reviews of research is a positive sign, since reviews tend to emerge and gain influence only after a field 
has generated a sufficient corpus of conceptual and empirical publications. This finding further reinforces the impression of a rapidly growing and maturing literature.

Nine of the 20 top-cited papers in Table 3 concern supply chain management, thereby reinforcing the results of journal citation analysis that placed this management discipline at the forefront of research on managing for sustainability. Key concepts and tools identified in this literature include life-cycle assessment [43], circular economy [44], and practices aimed at reducing waste, energy usage, and environmental impact. As noted above, this literature also evidences very strong contributions from Chinese scholars [19].

Table 3 also highlights a group of highly-cited papers focusing on "social entrepreneurship" [38,39,47,52]. In contrast to the environmental focus of the sustainable supply chain literature, entrepreneurship scholars have tended to give greater emphasis to social outcomes. Thananusak [16] concluded that this literature has examined "how entrepreneurs use innovation to drive the social mission of organizations" (p. 3577). Social entrepreneurship has been studied in relation to variance in the types of products produced by start-ups, job creation for under-served populations, engagement with stakeholders, and positive impact on communities [52].

A perusal of Table 3 also offers insight into the distribution of the key documents with respect to the triple bottom line of economic, social, and environmental outcomes of organizations and societies $[55,56]$. First, it is noted that most of these key papers addressed multiple outcomes. This most often concerned the nexus between social and economic [42] or environmental and economic outcomes [44]. Only two of these papers employed an in-depth analysis of triple bottom line outcomes [6,40]. This analysis further suggests that scholars studying entrepreneurship were more likely to focus on the "social" side of sustainability, while scholars associated with supply chain management were more likely to focus on environmental impact.

Document co-citation analysis yielded a complementary perspective on scholarly influence by highlighting key literature that has shaped the discourse on managing for sustainability. The only documents that featured in both the highly-cited and highly cocited tables were articles on sustainable supply chain management authored by Seuring and Müller [32], Pagell and Wu [48], and Hassini and colleagues [73]. It was also notable that 15 of the top co-cited documents were conceptual papers, four of which did not directly address "sustainability" (e.g., [37,62,66,74]). Instead, these highly co-cited documents proposed management theories that were applied in papers authored by "sustainability scholars" [63,67,70,72].

Some of these patterns highlighted in Table 4 were elaborated in a document cocitation map (see Figure 5) where the clusters can be interpreted as networks that represent "invisible colleges" [35] of scholars who have focused on similar lines of inquiry. By examining the composition of documents within each cluster the author was able to identify the conceptual themes that define these three "invisible colleges".

Table 4. Most highly co-cited documents in the seven sustainability management disciplines.

\begin{tabular}{|c|c|c|c|c|}
\hline Rank & Document & Domain $^{1}$ & Type $^{2}$ & Co-Citations \\
\hline 1 & $\begin{array}{l}\text { * Seuring and Müller (2008). From a literature review to a } \\
\text { conceptual framework for sustainable supply chain } \\
\text { management [32]. }\end{array}$ & S-SCM & $\operatorname{Rev}$ & 328 \\
\hline 2 & $\begin{array}{l}\text { Barney (1991). Firm resources and sustained competitive } \\
\text { advantage [37]. }\end{array}$ & Strategy & Con & 177 \\
\hline 3 & $\begin{array}{l}\text { Carter and Rogers (2008). Framework of sustainable supply } \\
\text { chain management: Moving toward new theory [57]. }\end{array}$ & S-SCM & Con & 166 \\
\hline 4 & $\begin{array}{l}\text { Eisenhardt (1989). Building theories from case study } \\
\text { research [58]. }\end{array}$ & Theory & Con & 147 \\
\hline 5 & $\begin{array}{l}\text { Zhu and Sarkis (2004). Relationships between operational } \\
\text { practices and performance among early adopters of green } \\
\text { supply chain [59]. }\end{array}$ & S-SCM & Emp & 104 \\
\hline
\end{tabular}


Table 4. Cont.

\begin{tabular}{|c|c|c|c|c|}
\hline Rank & Document & Domain $^{1}$ & Type $^{2}$ & Co-Citations \\
\hline 6 & $\begin{array}{l}\text { * Pagell and } \mathrm{Wu}(2009) . \text { Building a more complete theory of } \\
\text { sustainable supply chain management using case studies [48]. }\end{array}$ & S-SCM & Con & 90 \\
\hline 7 & $\begin{array}{l}\text { Vachon and Klassen (2008). Environmental management and } \\
\text { manufacturing performance: The role of collaboration [60]. }\end{array}$ & S-SCM & Con & 88 \\
\hline 8 & $\begin{array}{l}\text { Dean and McMullen. (2007). Toward a theory of sustainable } \\
\text { entrepreneurship [61]. }\end{array}$ & S-Entre & Con & 80 \\
\hline 9 & Hart (1995). A natural-resource-based view of the firm [62]. & Strategy & Con & 79 \\
\hline 10 & $\begin{array}{l}\text { Cohen and Winn. (2007). Market imperfections, opportunity, } \\
\text { and sustainable entrepreneurship [63]. }\end{array}$ & S-Entre & Con & 77 \\
\hline 11 & $\begin{array}{l}\text { Dyllick and Hockerts (2002). Beyond the business case for } \\
\text { corporate sustainability [64]. }\end{array}$ & Sustain & Con & 75 \\
\hline 12 & $\begin{array}{l}\text { Linton et al. (2007). Sustainable supply chains: } \\
\text { An introduction [65]. }\end{array}$ & S-SCM & Con & 75 \\
\hline 13 & $\begin{array}{l}\text { Teece et al. (1997). Dynamic capabilities and strategic } \\
\text { management [66]. }\end{array}$ & Strategy & Con & 75 \\
\hline 14 & Bai and Sarkis (2010b). Green supplier development [67]. & S-SCM & Con & 74 \\
\hline 15 & $\begin{array}{l}\text { Srivastava (2007). Green supply-chain management: } \\
\text { A state-of-the-art literature review [68]. }\end{array}$ & S-SCM & $\operatorname{Rev}$ & 73 \\
\hline 16 & $\begin{array}{l}\text { Rao and Holt (2005). Do green supply chains lead to } \\
\text { competitiveness and economic performance [69]? }\end{array}$ & S-SCM & Con & 69 \\
\hline 17 & $\begin{array}{l}\text { Schaltegger and Wagner. (2011). Sustainable entrepreneurship } \\
\text { and sustainability innovation [70]. }\end{array}$ & S-Entre & Con & 69 \\
\hline 18 & $\begin{array}{l}\text { Ahi and Searcy (2013). A comparative literature analysis of } \\
\text { definitions for green and sustainable supply chain } \\
\text { management [71]. }\end{array}$ & S-SCM & $\operatorname{Rev}$ & 67 \\
\hline 19 & $\begin{array}{l}\text { Seuring (2013). A review of modeling approaches for } \\
\text { sustainable supply chain management [72]. }\end{array}$ & S-SCM & Rev & 65 \\
\hline 20 & $\begin{array}{l}\text { * Hassini et al. (2012). A literature review and a case study of } \\
\text { sustainable supply chains with a focus on metrics [73]. }\end{array}$ & S-SCM & $\operatorname{Rev}$ & 64 \\
\hline 20 & $\begin{array}{l}\text { Nonaka (1994). Dynamic theory of organizational knowledge } \\
\text { creation [74]. }\end{array}$ & $\mathrm{KM}$ & Con & 64 \\
\hline
\end{tabular}

${ }^{*}$ This document also appeared among the most highly cited documents based on Scopus citation analysis. ${ }^{1}$ S-SCM = sustainable supply chain management; S-Entre = social entrepreneurship; KM = knowledge management; Sustain $=$ sustainability ${ }^{2}$ con $=$ conceptual; emp $=$ empirical; rev = review of research.

The central (red) cluster consists of 45 documents related to Strategic Management of Resources for Sustainability (SMRS). The lower green cluster comprised of 43 documents, concerns Sustainable Supply Chain Management [S-SCM]. The upper blue cluster refers to 23 documents related to Social Entrepreneurship [SE]. As indicated by the size and number of nodes, the S-SCM cluster has gained the highest co-citation impact. While specific documents associated with human resource management [75], knowledge management $[66,74,76,77]$, and innovation management [78] do appear on the map, they are integrated into the SE and SMRS clusters. Documents focusing on Organizational Leadership were absent from the map.

The central location and numerous links of the SMRS cluster to the other two clusters visualizes the centrality of strategic management within the broader field of sustainability management. SMRS documents frequently cited by management sustainability scholars focus on corporate social responsibility [40,79-81], competitive advantage $[37,49,55,69]$, shared value [81-83], dynamic capabilities [66], resource-based strategy [37,62,84], and absorptive capacity [78]. The presence of these conceptual documents, largely published outside the sustainability literature, reveals the "connective tissue" that binds this transdisciplinary field of study. These papers were frequently cited by authors of the "highlycited papers" featured earlier in Table $3[48,57,61,70,85]$. 


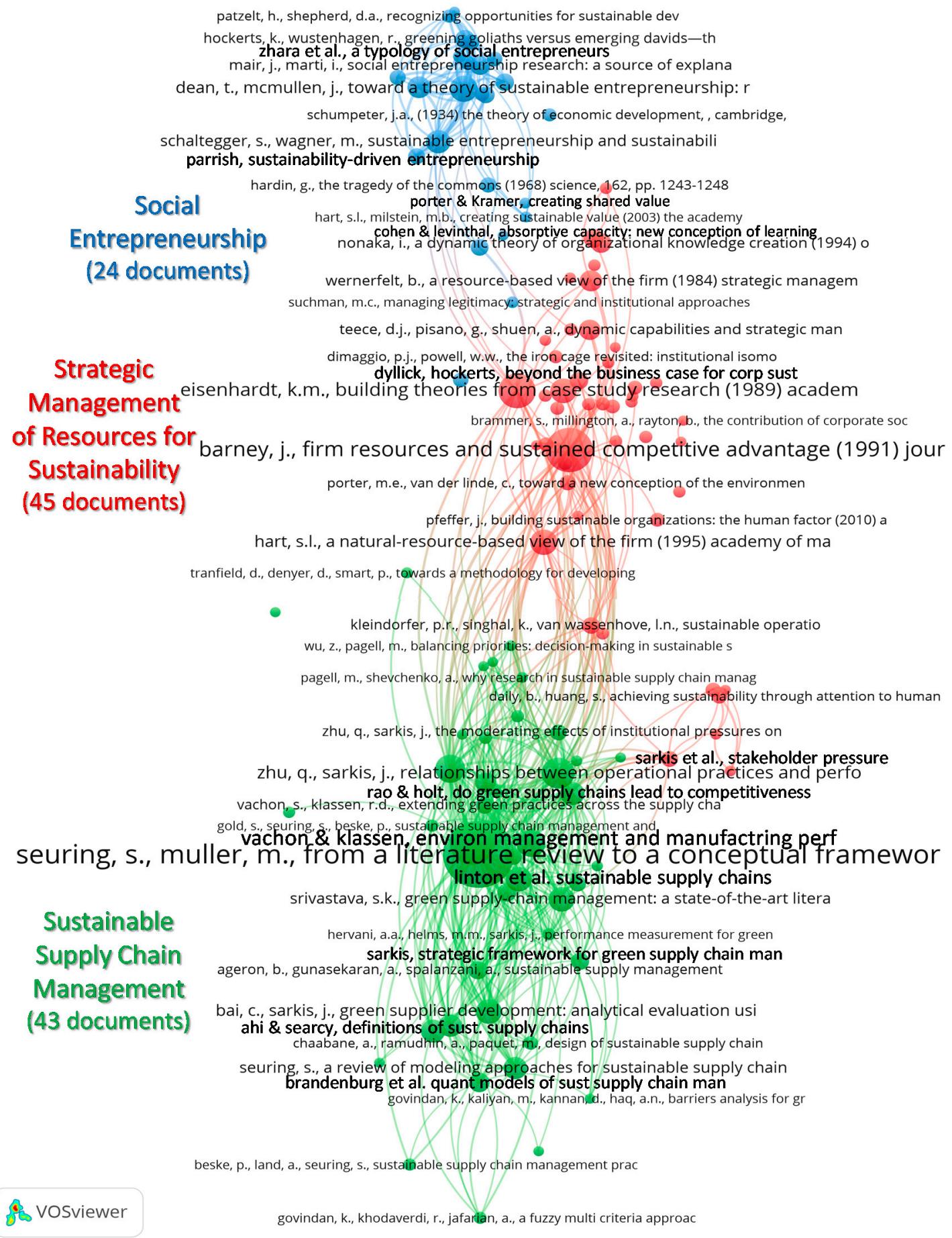

Figure 5. Document co-citation map of the literature on managing for sustainability (document co-citation network of 388,038 documents; threshold 20 citations, display 114 sources).

The map also visualizes tensions between the economic, social, and environmental pillars of sustainability research and practice. Documents located in the upper region of the map representing Social Entrepreneurship tend to emphasize the social dimensions of sustainability. These include stakeholder engagement, social change, and social justice $[38,39,86,87]$. In contrast, documents in the S-SCM cluster at the bottom of the map emphasize the environmental pillar of sustainability and impact $[32,68]$. Documents located in the central region of the map highlight the tension of managing to achieve social 
and environmental goals of the firm in the face of demands for economic performance and competition $[54,82,83,88,89]$.

\section{Discussion}

Due to the complex, systemic nature of global sustainability challenges, scholars have emphasized the need to employ trans-disciplinary approaches capable of overcoming the intellectual silos that separate individual disciplines [2,90,91]. Schaltegger and colleagues [91] concluded that "the very benefits of specialization create the corresponding challenge of re-integrating the scattered and often poorly compatible partial knowledge. In particular, disciplinary and functional specialization fails to create a sufficient understanding of system dynamics, interlinkages or overarching solutions" (p. 221). Consistent with this assertion, the current review aimed at synthesizing the efforts of different management disciplines to address these trans-disciplinary challenges. This section of the paper notes limitations and interprets the main findings of the review.

\subsection{Limitations}

Three limitations are worthy of note with respect to this review of research. First, although this review aimed at gaining a broad trans-disciplinary view on sustainability research in management, the effort remains incomplete. More specifically, the review did not include literature from operations, marketing and finance. Although there is some overlap with the literature on supply chain management, this review did not access documents related to other aspects of production and operations management. Concepts such as corporate social responsibility and sustainable consumption have attracted considerable attention in marketing [92,93]. In finance, topics such as risk management, microfinance, corporate investment, and corporate governance have emerged as important foci among sustainability researchers $[14,15]$. Future reviews should seek to integrate research from these management disciplines as well so as to gain a more complete perspective on managing for sustainability.

Second, by their nature, citation-based methods tend to emphasize dominant patterns that evolve within a literature. However, this mode of analysis runs the risk of casting nondominant but potentially important alternative paradigms into the shadows. For example, although organizational leadership did not emerge from this review as an influential field in the sustainability literature, scholars have asserted that organizational changes that seek to increase the priority on corporate social responsibility or reengineer supply chain processes require leadership [7,94]. With this in mind, readers are advised to consult the individual reviews on which this meta-synthesis was based, as well as reviews of these literatures that employed other review methods.

Third, as in any study that employs secondary data, the validity of this meta-synthesis depends on the accuracy, comprehensiveness, and comparability of data collected in the earlier research reviews. "Comprehensiveness" implies that the prior reviews each sourced most of the relevant documents from Scopus. "Accuracy" means that the primary databases included few "irrelevant documents". "Comparability" refers to the composition of the different datasets. Thus, it was earlier noted that some of the databases included "mixed document types", while others were limited to journal articles. Such differences are common in secondary analyses, and readers are advised to interpret the findings accordingly (e.g., when comparing the size of the sustainability knowledge bases in the different disciplines).

\subsection{Interpretation of the Findings}

This meta-synthesis of documents on managing for sustainability confirmed the existence of a body of research that is notable for its large size, disciplinary diversity, and scholarly impact. This corpus first emerged during the early 1980s and grew slowly over the next two decades. However, driven by growing recognition of the urgency and importance of the sustainability challenges facing nations throughout the world, this literature has 
grown exponentially over the past decade. More specifically, the review found that $78 \%$ of the Scopus-indexed documents published on sustainability in these seven management disciplines have been published since 2010. This publication trajectory suggests that this is a maturing literature which is gaining legitimacy in the scholarly community. Moreover, this growth trajectory portends that that this body of management research will more than double in size by 2030.

Although published documents on managing for sustainability were authored in 140 different societies, $60 \%$ of this review corpus originated in Anglo-American-European societies. When considered from the perspective of a global knowledge base, this geographical imbalance is a cause for concern. Sustainability challenges are predicted to impact developing societies with particular urgency, and these nations typically possess fewer resources to mitigate the effects [95]. Moreover, cultural attitudes shape national perceptions of the sense of urgency and subsequent responses to sustainability issues [96]. Thus, the findings documented in this review support the need for more research into how sustainability challenges are being "managed" by organizations in developing societies with attention to both similarities and differences with findings reported in economically developed societies.

At the same time, the review also documented a trend of increasing contributions from developing societies to this literature over the past decade. For example, during this period, management scholars from China, India, Malaysia, Brazil and South Africa have made significant contributions to our understanding of sustainable supply chain management [97]. Indeed, Chinese scholars rank among the world's leaders in this field of research and practice $[43,44,59,67,96-98]$. This emerging interest has been driven by the Chinese government's policy efforts to reduce the negative impact of development on the environment $[43,99,100]$. Unfortunately, a similar attention to research on the social pillar of sustainability has gained less attention [19,97]. This represents another priority area for future research.

The high level of journal and document citations produced by this literature suggests that research on "sustainability" is gaining scholarly acceptance in most of these different management disciplines. This perception was reinforced the findings that both mainstream scholars and those who specialize in sustainability rank among the intellectual leaders in this literature. Moreover, this knowledge base features a critical mass of publications in a diverse set of very high quality journals. These findings suggest two implications. First, they imply that sustainability has gone beyond the status of "fad" within the community of management scholars. Second, they further indicate that management scholars conducting research on sustainability issues do not have to sacrifice their aspirations for publishing in top-ranked journals. The second implication was also supported by the impressive range of subject domains represented by the journals publishing research on managing for sustainability. These include management, environmental science, business strategy, law, logistics, development, education, and information systems.

Citation analysis further identified the leading roles played by the Journal of Cleaner Production, Sustainability, International Journal of Production Economics, Business Strategy and the Environment, Resources, Conservation and Recycling, International Journal of Production Research, and Supply Chain Management. Scholars seeking to contribute to the literature on managing for sustainability should consider these and the other journals identified in Table 2 as high-profile journals with a track record of publishing research in this field.

Between-discipline analyses also found significant variation in the size and impact of the emerging knowledge base on sustainability in the seven functional management disciplines examined in this review. With caveats acknowledged earlier, knowledge management, innovation, and supply chain management have generated the most sustainabilityrelated scholarship. However, findings from citation analyses led to the conclusion that sustainability has gained greatest traction in supply chain management. This was evident in SCM's dominance among both leading journals (Journal of Cleaner Production, International 
Journal of Production Economics) and highly-cited documents (e.g., [32,48,57,73]). At the other end of the spectrum, the author was surprised by the relatively low level of interest in sustainability among scholars associated with human resource management [20]. The management of human resources holds several keys to corporate sustainability [75,101]. Indeed, scholars have identified the potent influence of HRM on corporate attitudes toward social responsibility, and the capacity of organizations to implement policies and practices associated with environmental sustainability $[8,20,49,101,102]$. This represents a significant gap in the sustainability management literature which should be addressed by HRM scholars [20]. Although the literature on organizational leadership was larger than HRM, it also failed to evidence significant citation impact [17].

Perhaps the most unanticipated finding to emerge from this meta-synthesis was the "hidden impact" of strategic management theories on discourse in managing for sustainability $[5,18,42,49]$. On the face of it, strategic management scholars have only shown a moderate level of interest in sustainability issues [18]. This was evident in the moderate size of the strategic management corpus sourced for the review, which was just over half the size of the sustainable supply chain document set. Moreover, strategic management scholars did not feature in the list of most highly-cited documents in this literature (i.e., Table 3). Indeed, it was only through co-citation analysis that the importance of "strategic perspectives" on managing for sustainability literature came to light.

Along with Social Entrepreneurship and Sustainable Supply Chain Management, document co-citation analysis identified Strategic Management for Sustainability as one of the three "invisible colleges" that comprise the literature on managing for sustainability. The document co-citation map further highlighted the "centrality" of strategic management theories on discourse in managing for sustainability literature (e.g., [37,62,66,81,103]). Theoretical documents elaborating concepts such as competitive advantage $[37,49,81,83,84]$, shared value $[5,82,104]$, resource-based strategies [37,84], stakeholder theory [80,103], dynamic capabilities [66], and the triple bottom line $[34,55,56]$ anchored the document cocitation map. The pattern of "links" between these documents and documents in the other two "colleges" (i.e., S-SCM and SE) provided visual documentation of how strategic management theories are influencing scholarship in other management disciplines. A similar pattern was observed on the journal co-citation map where Business Strategy and the Environment was identified as a key "boundary-spanning journal" connecting the different journal clusters.

The basis for this influence lies in the fact that strategic management theories seek to account for how organizations gain and sustain competitive advantage under different conditions. The sustainability challenges that have emerged over the past several decades represent changes in the environment of organizations to which they must respond. This review found that strategic management theories have provided the greatest intellectual leverage in analyzing organizational responses to sustainability whether the field is human resource management [20] or supply chain management [19].

\section{Conclusions}

With few exceptions, prior reviews of research on managing for sustainability have been conducted within specific management disciplines. This has tended to reinforce the intellectual silos in which scholars naturally operate [70]. This meta-synthesis identified a large, rapidly growing, trans-disciplinary literature on managing for sustainability [91]. The use of meta-synthesis afforded a "high ground" view of research on managing for sustainability capable of surfacing the connective tissue that binds these different management literatures into a whole. This finding represents a significant advance in elaborating the trans-disciplinary nature of managing for sustainability [91].

One important gap identified in the review lies in the need to broaden the coverage of this comparative assessment to include literature on sustainability in marketing (e.g., social marketing, sustainable consumption), finance (e.g., micro-credit, investment priorities and 
policies), and operations (e.g., sustainable production, waste management). This would round out the main functional management literatures.

The review also identified an imbalance in the production of literature from developed versus developing countries. This suggests a need for more studies that examine how organizations are managing for sustainability in developing societies. Fortunately, this has already begun to happen as evidenced by emerging concentrations of research in China [98], India [105], Brazil [106], and Malaysia [107]. Nonetheless, there remains a need for generating a critical mass of research from a broader, more representative cross-section of countries. Scholars who conduct research in developing societies should explicitly highlight how contextual factors such as cultural norms, institutional structures and resource availability shape sustainability challenges as well as how local knowledge is being used to craft effective solutions [96,105]. This will advance the knowledge base on managing for sustainability by creating knowledge that recognizes the contextualized nature of sustainability challenges and solutions.

Finally, it was noted that the literature reviewed in this paper emphasized managing for environmental sustainability $[20,33,43,44,50,97]$. Thus, this review urges scholars to give more explicit attention to the social pillar of managing for sustainability $[38,39,47,101]$, as well as its nexus with the other two pillars. As a first step, the field will benefit from a review of research on managing for social sustainability within and across the different management disciplines [52,108]. More broadly, it seems warranted to investigate the links between social and economic sustainability $[38,109]$. For example, to what extent do social factors (e.g., gender equality, ethical practices, shareholder engagement) contribute to the economic sustainability of firms $[5,8,88]$ ?

Finally, this review identified key journals, scholars, and documents that have shaped discourse in this trans-disciplinary literature [91]. Indeed, the journals and documents highlighted in this meta-synthesis represent useful resources for guiding emerging management scholars who are interested in sustainability toward relevant, high impact sources of knowledge. Moreover, findings from this review should encourage students studying sustainability management issues to look beyond their home "disciplines" (e.g., HRM, finance, supply chain management) when defining their research problems. This review has highlighted the necessity of going beyond the intellectual silos imposed by management disciplines and incorporating theoretical constructs from related disciplines [18,91]. Findings from this review also offer benchmarks against which the future evolution of this knowledge base can be assessed.

Funding: This research was funded by a grant (008/2561) from the Thailand Sustainable Development Foundation.

Data Availability Statement: The dataset used in this research is available from the author at hallinger@gmail.com. The author drew upon secondary databases extracted from Scopus and developed by the authors of seven prior reviews of research. The author recompiled and analyzed the datasets and wrote the paper.

Acknowledgments: The author wishes to thank and acknowledge the contributions of the following scholars who contributed the studies and related data on which this meta-synthesis was based: Astrid Kainzbauer, Suthep Nimsai, Phallapa Petison, Vichita Ractham, Parisa Rungruang, Patcharin Sanguankaew, Amaury-Alexandre Schaller, Randall Shannon, Suparak Suriyankietkaew, Trin Thananusak, Ronald Vatananan-Thesenvitz, and Chanin, Yoopetch. The research for this project was funded by the Thailand Sustainable Development Foundation.

Conflicts of Interest: The author declares no known competing financial interests or personal relationships that could have appeared to influence the work reported in this paper.

\section{References}

1. Brundtland, G.H.; Khalid, M.; Agnelli, S.; Al-Athel, S.; Chidzero, B.J. Our Common Future; WCED: New York, NY, USA, 1987.

2. Hassan, S.U.; Haddawy, P.; Zhu, J.A. bibliometric study of the world's research activity in sustainable development and its sub-areas using scientific literature. Scientometrics 2014, 99, 549-579. [CrossRef] 
3. Huckle, J.; Wals, A.E. The UN Decade of Education for Sustainable Development: Business as usual in the end. Environ. Educ. Res. 2015, 21, 491-505. [CrossRef]

4. Jickling, B.; Wals, A.E. Debating education for sustainable development 20 years after Rio: A conversation between Bob Jickling and Arjen Wals. J. Educ. Sustain. Dev. 2012, 6, 49-57. [CrossRef]

5. Baumgartner, R.J. Managing corporate sustainability and CSR: A conceptual framework combining values, strategies and instruments contributing to sustainable development. Corp. Soc. Responsib. Environ. Manag. 2014, 21, 258-271. [CrossRef]

6. Seyfang, G.; Smith, A. Grassroots innovations for sustainable development: Towards a new research and policy agenda. Environ. Politics 2007, 16, 584-603. [CrossRef]

7. Visser, W.; Courtice, P. Sustainability Leadership: Linking Theory and Practice. 2011. Available online: https://ssrn.com/ abstract $=1947221$ (accessed on 26 August 2018).

8. Aguinis, H.; Glavas, A. What we know and corporate social responsibility: A review and research agenda. J. Manag. 2012, 38, 932-968.

9. Goyal, P.; Rahman, Z.; Kazmi, A.A. Corporate sustainability performance and firm performance research: Literature review and future research agenda. Manag. Decis. 2013, 51, 361-379. [CrossRef]

10. Salzmann, O.; Ionescu-Somers, A.; Steger, U. The business case for corporate sustainability: Literature review and research options. Eur. Manag. J. 2005, 23, 27-36. [CrossRef]

11. Searcy, C. Corporate sustainability performance measurement systems: A review and research agenda. J. Bus. Ethics 2012, 107, 239-253. [CrossRef]

12. De Medeiros, J.F.; Ribeiro, J.L.D.; Cortimiglia, M.N. Success factors for environmentally sustainable product innovation: A systematic literature review. J. Clean. Prod. 2014, 65, 76-86. [CrossRef]

13. Fahimnia, B.; Sarkis, J.; Davarzani, H. Green supply chain management: A review and bibliometric analysis. Int. J. Prod. Econ. 2015, 162, 101-114. [CrossRef]

14. Zaby, S. Science mapping of the global knowledge base on microfinance: Influential authors and documents, 1989-2019. Sustainability 2019, 11, 3883. [CrossRef]

15. Zheng, C.; Kouwenberg, R. A bibliometric review of global research on corporate governance and board attributes. Sustainability 2019, 11, 3428. [CrossRef]

16. Thananusak, T. Science mapping of the knowledge base on sustainable entrepreneurship, 1996-2019. Sustainability 2019, 11, 3565. [CrossRef]

17. Hallinger, P.; Suriyankietkaew, S. Science mapping of the knowledge base on sustainable leadership, 1990-2018. Sustainability 2018, 10, 4846. [CrossRef]

18. Suriyankietkaew, S.; Petison, P. A retrospective and foresight: Bibliometric review of international research on strategic management for sustainability, 1991-2019. Sustainability 2020, 12, 91. [CrossRef]

19. Nimsai, S.; Yoopetch, C.; Lai, P. Mapping the knowledge base of sustainable supply chain management: A bibliometric literature review. Sustainability 2020, 12, 7348. [CrossRef]

20. Kainzbauer, A.; Rungruang, P. Science mapping the knowledge base on sustainable human resource management, 1982-2019. Sustainability 2019, 11, 3938. [CrossRef]

21. Sanguankaew, P.; Vathanophas Ractham, V. Bibliometric review of research on knowledge management and sustainability, 1994-2018. Sustainability 2019, 11, 4388. [CrossRef]

22. Vatananan-Thesenvitz, R.; Schaller, A.A.; Shannon, R. A bibliometric review of the knowledge base for innovation in sustainable development. Sustainability 2019, 11, 5783. [CrossRef]

23. Van Eck, N.J.; Waltman, L.; Dekker, R.; van den Berg, J. A comparison of two techniques for bibliometric mapping: Multidimensional scaling and VOS. J. Am. Soc. Inf. Sci. Technol. 2010, 61, 2405-2416. [CrossRef]

24. Van Eck, N.J.; Waltman, L. Visualizing bibliometric networks. In Measuring Scholarly Impact; Ding, Y., Rousseau, R., Wolfram, D., Eds.; Springer: Berlin/Heidelberg, Germany, 2014; pp. 285-320.

25. Zupic, I.; Čater, T. Bibliometric methods in management and organization. Organ. Res. Methods 2015, 18, 429-472. [CrossRef]

26. Mongeon, P.; Paul-Hus, A. The journal coverage of Web of Science and Scopus: A comparative analysis. Scientometrics 2016, 106, 213-228. [CrossRef]

27. Moher, D.; Liberati, A.; Tetzlaff, J.; Altman, D.G. Preferred reporting items for systematic reviews and meta-analyses: The PRISMA statement. Ann. Intern. Med. 2009, 151, 264-269. [CrossRef]

28. Meho, L.I. The rise and rise of citation analysis. Phys. World 2007, 20, 32. [CrossRef]

29. Smith, L.C. Citation analysis. Libr. Trends 1981, 31, 83-106.

30. Hallinger, P.; Kovačević, J. A bibliometric review of research on educational administration: Science mapping the literature, 1960 to 2018. Rev. Educ. Res. 2019, 89, 335-369. [CrossRef]

31. Small, H. Co-citation in the scientific literature: A new measure of the relationship between two documents. J. Am. Soc. Inf. Sci. 1973, 24, 265-269. [CrossRef]

32. Seuring, S.; Müller, M. Core issues in sustainable supply chain management-A Delphi study. Bus. Strategy Environ. 2008, 17, 455-466. [CrossRef]

33. Vachon, S.; Klassen, R.D. Extending green practices across the supply chain: The impact of upstream and downstream integration. Int. J. Oper. Prod. Manag. 2006, 26, 795-821. [CrossRef] 
34. Govindan, K.; Khodaverdi, R.; Jafarian, A. A fuzzy multi criteria approach for measuring sustainability performance of a supplier based on triple bottom line approach. J. Clean. Prod. 2013, 47, 345-354. [CrossRef]

35. Gmür, M. Co-citation analysis and the search for invisible colleges: A methodological evaluation. Scientometrics 2003, 57, 27-57. [CrossRef]

36. Ding, Y.; Chowdhury, G.G.; Foo, S. Journal as markers of intellectual space: Journal co-citation analysis of information retrieval area, 1987-1997. Scientometrics 2000, 47, 55-73. [CrossRef]

37. Barney, J. Firm resources and sustained competitive advantage. J. Manag. 1991, 17, 99-120. [CrossRef]

38. Austin, J.; Stevenson, H.; Wei-Skillern, J. Social and commercial entrepreneurship: Same, different, or both? Entrep. Theory Pract. 2006, 30, 1-22. [CrossRef]

39. Mair, J.; Marti, I. Social entrepreneurship research: A source of explanation, prediction, and delight. J. World Bus. 2006, 41, 36-44. [CrossRef]

40. Bansal, P. Evolving sustainably: A longitudinal study of corporate sustainable development. Strateg. Manag. J. 2005, 26, 197-218. [CrossRef]

41. Edvinsson, L. Developing intellectual capital at Skandia. Long Range Plan. 1997, 30, 366-373. [CrossRef]

42. Schot, J.; Geels, F.W. Strategic niche management and sustainable innovation journeys: Theory, findings, research agenda, and policy. Technol. Anal. Strateg. Manag. 2008, 20, 537-554. [CrossRef]

43. Zhu, Q.; Sarkis, J.; Geng, Y. Green supply chain management in China: Pressures, practices and performance. Int. J. Oper. Prod. Manag. 2005, 25, 449-468. [CrossRef]

44. Zhu, Q.; Sarkis, J.; Lai, K.H. Green supply chain management: Pressures, practices and performance within the Chinese automobile industry. J. Clean. Prod. 2007, 15, 1041-1052. [CrossRef]

45. Chesbrough, H.; Crowther, A.K. Beyond high tech: Early adopters of open innovation in other industries. RD Manag. 2006, 36, 229-236. [CrossRef]

46. Bettencourt, L.M.; Lobo, J.; Helbing, D.; Kühnert, C.; West, G.B. Growth, innovation, scaling, and the pace of life in cities. Proc. Natl. Acad. Sci. USA 2007, 104, 7301-7306. [CrossRef] [PubMed]

47. Zahra, S.A.; Gedajlovic, E.; Neubaum, D.O.; Shulman, J.M. A typology of social entrepreneurs: Motives, search processes and ethical challenges. J. Bus. Ventur. 2009, 24, 519-532. [CrossRef]

48. Pagell, M.; Wu, Z. Building a more complete theory of sustainable supply chain management using case studies of 10 exemplars. J. Supply Chain Manag. 2009, 45, 37-56. [CrossRef]

49. Hatch, N.W.; Dyer, J.H. Human capital and learning as a source of sustainable competitive advantage. Strateg. Manag. J. 2004, 25, 1155-1178. [CrossRef]

50. Walker, H.; Di Sisto, L.; McBain, D. Drivers and barriers to environmental supply chain management practices: Lessons from the public and private sectors. J. Purch. Supply Manag. 2008, 14, 69-85. [CrossRef]

51. Phaal, R.; Farrukh, C.J.; Probert, D.R. Technology roadmapping-a planning framework for evolution and revolution. Technol. Forecast. Soc. Chang. 2004, 71, 5-26. [CrossRef]

52. Peredo, A.M.; McLean, M. Social entrepreneurship: A critical review of the concept. J. World Bus. 2006, 41, 56-65. [CrossRef]

53. McNie, E.C. Reconciling the supply of scientific information with user demands: An analysis of the problem and review of the literature. Environ. Sci. Policy 2007, 10, 17-38. [CrossRef]

54. Wong, K. Critical success factors for implementing knowledge management in small and medium enterprises. Ind. Manag. Data Syst. 2005, 105, 261-279. [CrossRef]

55. Elkington, J. Partnerships from cannibals with forks: The triple bottom line of 21st-century business. Environ. Qual. Manag. 1998, 8, 37-51. [CrossRef]

56. Elkington, J. Towards the sustainable corporation: Win-win-win business strategies for sustainable development. Calif. Manag. Rev. 1994, 36, 90-100. [CrossRef]

57. Carter, C.R.; Rogers, D.S. A framework of sustainable supply chain management: Moving toward new theory. Int. J. Phys. Distrib. Logist. Manag. 2008, 38, 360-387. [CrossRef]

58. Eisenhardt, K.M. Building theories from case study research. Acad. Manag. Rev. 1989, 14, 532-550. [CrossRef]

59. Zhu, Q.; Sarkis, J. Relationships between operational practices and performance among early adopters of green supply chain management practices in Chinese manufacturing enterprises. J. Oper. Manag. 2004, 22, 265-289. [CrossRef]

60. Vachon, S.; Klassen, R.D. Environmental management and manufacturing performance: The role of collaboration in the supply chain. Int. J. Prod. Econ. 2008, 111, 299-315. [CrossRef]

61. Dean, T.J.; McMullen, J.S. Toward a theory of sustainable entrepreneurship: Reducing environmental degradation through entrepreneurial action. J. Bus. Ventur. 2007, 22, 50-76. [CrossRef]

62. Hart, S.L. A natural-resource-based view of the firm. Acad. Manag. Rev. 1995, 20, 986-1014. [CrossRef]

63. Cohen, B.; Winn, M.I. Market imperfections, opportunity and sustainable entrepreneurship. J. Bus. Ventur. 2007, 22, 29-49. [CrossRef]

64. Dyllick, T.; Hockerts, K. Beyond the business case for corporate sustainability. Bus. Strategy Environ. 2002, 11, 130-141. [CrossRef]

65. Linton, J.D.; Klassen, R.; Jayaraman, V. Sustainable supply chains: An introduction. J. Oper. Manag. 2007, 25, 1075-1082. [CrossRef]

66. Teece, D.J.; Pisano, G.; Shuen, A. Dynamic capabilities and strategic management. Strateg. Manag. J. 1997, 18, 509-533. [CrossRef] 
67. Bai, C.; Sarkis, J. Integrating sustainability into supplier selection with grey system and rough set methodologies. Int. J. Prod. Econ. 2010, 124, 252-264. [CrossRef]

68. Srivastava, S.K. Green supply-chain management: A state-of-the-art literature review. Int. J. Manag. Rev. 2007, 9, 53-80. [CrossRef]

69. Rao, P.; Holt, D. Do green supply chains lead to competitiveness and economic performance? Int. J. Oper. Prod. Manag. 2005, 25, 898-916. [CrossRef]

70. Schaltegger, S.; Wagner, M. Sustainable entrepreneurship and sustainability innovation: Categories and interactions. Bus. Strategy Environ. 2011, 20, 222-237. [CrossRef]

71. Ahi, P.; Searcy, C. A comparative literature analysis of definitions for green and sustainable supply chain management. J. Clean. Prod. 2013, 52, 329-341. [CrossRef]

72. Seuring, S. A review of modeling approaches for sustainable supply chain management. Decis. Support Syst. 2013, 54, 1513-1520. [CrossRef]

73. Hassini, E.; Surti, C.; Searcy, C. A literature review and a case study of sustainable supply chains with a focus on metrics. Int. J. Prod. Econ. 2012, 140, 69-82. [CrossRef]

74. Nonaka, I. A dynamic theory of organizational knowledge creation. Organ. Sci. 1994, 5, 14-37. [CrossRef]

75. Pfeffer, J. Building sustainable organizations: The human factor. Acad. Manag. Perspect. 2010, 24, 34-45.

76. March, J.G. Exploration and exploitation in organizational learning. Organ. Sci. 1991, 2, 71-87. [CrossRef]

77. Nahapiet, J.; Ghoshal, S. Social capital, intellectual capital, and the organizational advantage. Acad. Manag. Rev. 1998, 23, 242-266. [CrossRef]

78. Cohen, W.M.; Levinthal, D.A. Absorptive capacity: A new perspective on learning and innovation. Adm. Sci. Q. 1990, 35, 128-152. [CrossRef]

79. Brammer, S.; Millington, A.; Rayton, B. The contribution of corporate social responsibility to organizational commitment. Int. J. Hum. Resour. Manag. 2007, 18, 1701-1719. [CrossRef]

80. Carroll, A.B. The pyramid of corporate social responsibility: Toward the moral management of organizational stakeholders. Bus. Horiz. 1991, 34, 39-48. [CrossRef]

81. Porter, M.E.; Kramer, M.R. The link between competitive advantage and corporate social responsibility. Harv. Bus. Rev. 2006, 84, 78-92. [PubMed]

82. Hart, S.L.; Milstein, M.B. Creating sustainable value. Acad. Manag. Perspect. 2003, 17, 56-67. [CrossRef]

83. Porter, M.E.; Van der Linde, C. Toward a new conception of the environment-competitiveness relationship. J. Econ. Perspect. 1995, 9, 97-118. [CrossRef]

84. Wernerfelt, B. A resource-based view of the firm. Strateg. Manag. J. 1984, 5, 171-180. [CrossRef]

85. Sarkis, J.; Zhu, Q.; Lai, K.H. An organizational theoretic review of green supply chain management literature. Int. J. Prod. Econ. 2011, 130, 1-15. [CrossRef]

86. Schumpeter, J.A. The theory of economic development, translated by Redvers Opie. Harv. Econ. Stud. 1934, 46, $1600-0404$.

87. Seelos, C.; Mair, J. Social entrepreneurship: Creating new business models to serve the poor. Bus. Horiz. 2005, 48, 241-246. [CrossRef]

88. Orlitzky, M.; Schmidt, F.L.; Rynes, S.L. Corporate social and financial performance: A meta-analysis. Organ. Stud. 2003, 24, 403-441. [CrossRef]

89. Wu, Z.; Pagell, M. Balancing priorities: Decision-making in sustainable supply chain management. J. Oper. Manag. 2011, 29, 577-590. [CrossRef]

90. Brandt, P.; Ernst, A.; Gralla, F.; Luederitz, C.; Lang, D.J.; Newig, J.; von Wehrden, H. A review of transdisciplinary research in sustainability science. Ecol. Econ. 2013, 92, 1-15. [CrossRef]

91. Schaltegger, S.; Beckmann, M.; Hansen, E.G. Transdisciplinarity in corporate sustainability: Mapping the field. Bus. Strategy Environ. 2013, 22, 219-229. [CrossRef]

92. Gordon, R.; Carrigan, M.; Hastings, G. A framework for sustainable marketing. Mark. Theory 2011, 11, 143-163. [CrossRef]

93. Peattie, K.; Peattie, S. Social marketing: A pathway to consumption reduction? J. Bus. Res. 2009, 62, 260-268. [CrossRef]

94. Benn, S.; Edwards, M.; Williams, T. Organizational Change for Corporate Sustainability; Routledge: London, UK, 2014.

95. Sachs, J.D. The Age of Sustainable Development; Columbia University Press: New York, NY, USA, 2015.

96. Crabbe, M.J. Challenges for sustainability in cultures where regard for the future may not be present. Sustain. Sci. Pract. Policy 2006, 2, 57-61.

97. det Udomsap, A.; Hallinger, P. A bibliometric review of research on sustainable construction, 1994-2018. J. Clean. Prod. 2020, 254, 120073. [CrossRef]

98. Xiang, W.N.; Stuber, R.M.; Meng, X. Meeting critical challenges and striving for urban sustainability in China. Landsc. Urban Plan. 2011, 100, 418-420. [CrossRef]

99. Bai, C.; Sarkis, J. Green supplier development: Analytical evaluation using rough set theory. J. Clean. Prod. 2010, 18, 1200-1210. [CrossRef]

100. Geng, Y.; Fu, J.; Sarkis, J.; Xue, B. Towards a national circular economy indicator system in China: An evaluation and critical analysis. J. Clean. Prod. 2012, 23, 216-224. [CrossRef]

101. Jabbour, C.J.C.; de Sousa Jabbour, A.B.L. Green human resource management and green supply chain management: Linking two emerging agendas. J. Clean. Prod. 2016, 112, 1824-1833. [CrossRef] 
102. Renwick, D.W.; Redman, T.; Maguire, S. Green human resource management: A review and research agenda. Int. J. Manag. Rev. 2013, 15, 1-14. [CrossRef]

103. Freeman, R.E. Strategic Management: A Stakeholder Approach; Cambridge University Press: Cambridge, UK, 2010.

104. Porter, M.E.; Kramer, M.R. Creating shared value. In Managing Sustainable Business; Springer: Dordrecht, The Netherlands, 2019; pp. 323-346.

105. Mani, V.; Gunasekaran, A.; Papadopoulos, T.; Hazen, B.; Dubey, R. Supply chain social sustainability for developing nations: Evidence from India. Resour. Conserv. Recycl. 2016, 111, 42-52. [CrossRef]

106. Munasinghe, M.; Jayasinghe, P.; Deraniyagala, Y.; Matlaba, V.J.; dos Santos, J.F.; Maneschy, M.C.; Mota, J.A. Value-supply chain analysis VSCA of crude palm oil production in Brazil, focusing on economic, environmental and social sustainability. Sustain. Prod. Consum. 2019, 17, 161-175. [CrossRef]

107. Zahid, M.; Rahman, H.U.; Ali, W.; Khan, M.; Alharthi, M.; Qureshi, M.I.; Jan, A. Boardroom gender diversity: Implications for corporate sustainability disclosures in Malaysia. J. Clean. Prod. 2020, 244, 118683. [CrossRef]

108. Alvord, S.H.; Brown, L.D.; Letts, C.W. Social entrepreneurship and societal transformation: An exploratory study. J. Appl. Behav. Sci. 2004, 40, 260-282. [CrossRef]

109. Schönborn, G.; Berlin, C.; Pinzone, M.; Hanisch, C.; Georgoulias, K.; Lanz, M. Why social sustainability counts: The impact of corporate social sustainability culture on financial success. Sustain. Prod. Consum. 2019, 17, 1-10. [CrossRef] 